\title{
A NEW MODIFIED PROTAMINE ZINC INSULIN: COMPARISON WITH HISTONE ZINC INSULIN, CLEAR, AND STANDARD PROTAMINE ZINC INSULINS ${ }^{1,2}$
}

\author{
By CYRIL M. MAcBRYDE aNd HAROLD K. ROBERTS \\ (From the Department of Internal Medicine, Washington University School of Medicine, \\ and the Barnes Hospital, St. Louis)
}

(Received for publication December 30, 1942)

Patients with diabetes who require more than 40 units of insulin per day are usually best controlled by giving a large dose of protamine zinc insulin and a smaller dose of regular (or crystalline) insulin, before breakfast, daily (1). Standard protamine zinc insulin does not have sufficient rapid activity to control the hyperglycemia occurring after meals in patients with severe diabetes. In such cases, attempts to eliminate glycosuria during the day by increasing the dose of protamine zinc insulin tend to cause hypoglycemia during the night. When the diabetes is mild, requiring 40 units or less per day, the rise in the blood sugar after food intake may not be great, and a single dose of protamine zinc insulin daily may permit good regulation. A night feeding at 9 or 10 p.m. helps to prevent nocturnal hypoglycemia. Among 154 patients satisfactorily regulated during the period between January 1, 1940, and July 1, 1942, we found that "combined therapy," with separate daily injections of protamine zinc insulin and regular insulin, was necessary in 57 cases ( 37 per cent). In the period of $2 \frac{1}{2}$ years, the average dose given the 97 patients requiring protamine zinc insulin alone was 24 units, while the average total daily requirement of the 57 patients needing combined therapy was 57 units. Of the 54 patients requiring more than 40 units of insulin daily, 47 (87 per cent) required combined therapy.

The primary objection to combined therapy is that it is a compromise, still requiring multiple

\footnotetext{
1 These studies were reported at the annual meeting of the Central Society for Clinical Research, Chicago, November 6,1942, in a paper entitled: "Three-to-One" Modified Protamine Zinc Insulin; An Improvement Upon Market Protamine Zinc Insulin.

2 The non-standard forms of modified insulin used in these investigations were supplied by Eli Lilly and Company.
}

injections, thus partly nullifying one of the chief advantages of protamine zinc insulin. A second objection is that it requires manipulation by the patient of 2 very different forms of insulin and increases the possibilities of error. Many investigators have been aware of these objections and a number of studies of various insulin modifications have been reported.

Histone insulin, made by adding to insulin the simple protein, histone, obtained from thymus glands, was introduced by Hagedorn, Jensen, Krarup, and Wodstrup (2). It was studied clinically by Biasotti, Deulofeu, and Mendive (3), and Gray, Bischoff, and Sansum (4). Barnes, Cuttle, and Duncan (5) studied histone insulin to which zinc had been added. They concluded that histone zinc insulin gave a prolonged effect, but was more prompt in onset of action than protamine zinc insulin. Bailey and Marble (6) found that a single adequate dose of histone zinc insulin before breakfast kept the fasting blood sugars within approximately normal limits in the 4 patients studied. Glycosuria was well controlled, and there was very little rise in the blood sugar after breakfast, but a considerable rise after lunch. They concluded that "the action of histone zinc insulin resembles closely that of turbid protamine zinc insulin except for the initial action just described and probably for a slightly less prolonged effect."

Clear (soluble or acid) protamine zinc insulin has a pH of 3.3 to 3.5 , at which the material is all in solution. It also contains more protamine and more zinc than turbid protamine zinc insulin. Bailey and Marble (6), in a recent report of comparative studies in 4 patients, found that the fasting blood sugars were quite high and that regulation with clear protamine zinc insulin was difficult. They found that with it a relatively large increase in the blood sugar occurred between 7 and 11 a.m., with a fall between 11 a.m. and 2 p.m., and 
a great decrease between 2 and 5 p.m., requiring a mid-afternoon lunch to prevent reactions.

Several investigators (6) have concluded that the use of globin insulin required a mid-afternoon lunch to prevent hypoglycemic reactions. This would make it unsatisfactory for many patients. An excellent review of the various types of modified insulin, with a table giving their descriptions, was presented by Colwell, Izzo, and Stryker (7).

The present paper presents our investigations of histone zinc insulin, clear (soluble or acid) protamine zinc insulin, and a new, more promising modified protamine zinc insulin.

\section{SELECTION OF A STANDARD MODIFIED PROTAMINE} ZINC INSULIN

In the 57 cases in our series requiring combined therapy with separate daily injections of protamine zinc insulin and regular insulin, the proportion of protamine zinc insulin to regular insulin ranged from $6: 1$ to $1.2: 1$, averaging $3: 1$. Forty-five of the 57 ( 79 per cent) required a proportion between $2: 1$ and $4: 1$, while 29 (51 per cent) required between $2.5: 1$ and $3.5: 1$. Joslin (8) found that over 50 per cent of a recently analyzed series of diabetic patients required combined therapy, and that the average proportion needed was $3: 1$.

Because the studies here reported indicate that histone zinc insulin and clear protamine zinc insulin fail to give the desirable $3: 1$ proportional effect, it seemed desirable to prepare an insulin with 75 per cent slow effect and 25 per cent rapid effect, and to compare the control obtainable with it with the regulation secured with other forms of insulin therapy. Since the studies of Wauchope (9) and of Ulrich (10) suggested that insulins with intermediate activity can be made by mixing protamine zinc insulin and regular insulin, we returned to the study of mixtures. We previously had confirmed the observations of Bjuggren (11), Masters (12), and others, that when protamine zinc insulin and regular insulin are mixed in the proportions commonly employed in the combined method of therapy, all of the insulin is precipitated by the excess of protamine present. We therefore have not adopted the practice of Wilder (13) and his associates of using mixtures varying with each patient.
Several preparations having approximately the desired proportional effects were obtained by mixing various amounts of protamine zinc insulin and regular insulin. Standard protamine zinc insulin contains an excess of about 40 per cent of protamine. The amounts of soluble and of precipitated insulin present after admixture, and therefore the relative rapidity of action, depend upon the excess of protamine present, the quantities of the $2 \mathrm{insu-}$ lins used, and the $\mathrm{pH}$. The effects of the relative proportions have been well presented by Peck (14). A mixture of equal parts results in combination of all of the excess protamine, and should leave 60 per cent of the regular insulin (i.e., 30 per cent of the total units) in soluble form. However, when such a mixture was centrifuged, all of the insulin was found to be precipitated. This resulted from the fact that the $\mathrm{pH}$ of the mixture was close to 5 , the iso-electric point of insulin. Minor alterations, either to the acid to to the alkaline side of $\mathrm{pH} 5$, resulted in uncertain amounts of the regular insulin remaining in solution. If equal parts of protamine zinc insulin and regular insulin were mixed and the $\mathrm{pH}$ adjusted to 7.2, this uncertainty was avoided, and the $\mathrm{pH}$ of the insulin is approximately that of the body fluids. Assay of this form of modified protamine zinc insulin revealed that 75 per cent of the insulin was precipitated, and 25 per cent was soluble.

This special modification was selected for further study because it contains the desirable proportion of 3 parts precipitated insulin to 1 part of soluble insulin. For convenience and clarity in the rest of this paper, it is referred to as " $3: 1$ " insulin. ${ }^{3}$ The characteristics of this insulin, compared with the other modified insulins studied and with standard insulins, are given in Table I.

\section{METHOD OF INVESTIGATION}

Each patient studied remained in the hospital on the metabolism ward for several weeks. A carefully weighed diet was given, and the diet was not changed throughout the study period. Likewise, no appreciable variation in

${ }^{3}$ Our first preparations of this material were made in our laboratory. Most of the studies here reported were made with the same material supplied to us by the Lilly Research Laboratories with the experimental label "Special Protamine Zinc Insulin," lots T-1652 and T-1716.

The designation " $3: 1$ " should not be confused with simple mixtures such as "Insulin and Protamine Zinc Insulin, 2 to 1 Mixture," etc. 
physical activity was permitted, so that as nearly as possible, the only factor altered from one study period to the next was the character of the insulin. The patients' ages ranged from 25 to 74 years, averaging about 50 years.

Each patient was as carefully regulated as possible on one type of insulin. Frequent blood sugar determinations were obtained, and careful quantitative urine sugar determinations were done in 4 fractional periods : 7 a.m. to 11 a.m., 11 a.m. to 4 p.m., 4 p.m. to 9 p.m., and 9 p.m. to 7 a.m. Meals were given at 8 a.m., 12 noon and 5 p.m. A night feeding at 9:30 p.m. to 10 p.m. was given in practically all cases, as a rule containing 30 grams of carbohydrate. The diets used were those thought to be best for each individual patient, and therefore varied considerably. The carbohydrate allowances ranged from 150 to $220 \mathrm{grams}$, fat from 30 to $\mathbf{1 7 0}$ grams, protein from $\mathbf{5 6}$ to 92 grams, according to the age, size, nutritional status, and caloric requirements of each patient. The carbohydrate distribution usually allowed 20 per cent in the night feeding, while in the majority of cases, the remaining 80 per cent was divided equally between the 3 main meals. In certain cases, a somewhat larger proportion was given at lunch and supper. The average patient, who received 150 grams of carbohydrate daily, had it distributed as $40,40,40$, and 30 grams, respectively, among the 4 feedings.

When glycosuria had been practically eliminated and blood sugars all fell within practically normal limits, all conditions were kept constant, including diet, activity, and insulin dose. If any complication such as fever, infection, change in activity, or mistake in diet arose, the data were discarded. After at least 4 to 7 days of stable blood sugar levels, 24-hour blood sugar curves were determined. Blood for sugar determinations was taken at $7: 30$ a.m. (fasting), $10: 30$ a.m., $2: 30$ p.m., $7: 30$ p.m., 12 midnight, and again at 7:30 a.m. (fasting). The blood sugars at 10:30 a.m., 2:30 p.m., 7:30 p.m. and at midnight each represent the level existing $2 \frac{1}{2}$ hours after the preceding meal. The constancy of these intervals lends additional meaning to curves constructed from such

TABLE I

Characteristics of insulins studied compared with standard insulins

\begin{tabular}{|c|c|c|c|c|c|}
\hline \multirow{2}{*}{ Insulin } & \multirow{2}{*}{$\begin{array}{l}\text { Source } \\
\text { of } \\
\text { added } \\
\text { protein }\end{array}$} & \multirow{2}{*}{$\begin{array}{l}\text { Char- } \\
\text { acter }\end{array}$} & \multirow{2}{*}{$\mathbf{p H}$} & \multicolumn{2}{|c|}{$\begin{array}{l}\text { Composition per } \\
100 \text { units }\end{array}$} \\
\hline & & & & $\begin{array}{l}\text { Added } \\
\text { protein }\end{array}$ & Zinc \\
\hline $\begin{array}{l}\text { "Three-to-one" } \\
\text { protamine zinc } \\
\text { Histone zinc } \\
\text { Clear protamine } \\
\text { zinc } \\
\text { Globin (zinc) }\end{array}$ & $\begin{array}{l}\text { Salmon } \\
\text { sperm } \\
\text { Thymus } \\
\text { Salmon } \\
\text { sperm } \\
\text { Beef } \\
\text { blood }\end{array}$ & $\begin{array}{l}\text { Turbid } \\
\text { Turbid } \\
\text { Clear } \\
\text { Clear }\end{array}$ & $\begin{array}{c}7.1 \text { to } 7.2 \\
\begin{array}{c}7.0 \\
3.3 \text { to } 3.5 \\
3.7\end{array}\end{array}$ & $\begin{array}{c}\text { mgm. } \\
\text { Approx. } \\
0.67 \\
3.2 \\
3.8 \\
3.75\end{array}$ & $\begin{array}{c}\text { mgm. } \\
0.1 \\
0.2 \\
0.31 \\
0.31\end{array}$ \\
\hline $\begin{array}{l}\text { Turbid (market) } \\
\text { protamine zinc } \\
\text { Regular } \\
\text { Crystalline }\end{array}$ & $\begin{array}{l}\text { Salmon } \\
\text { sperm } \\
\text { None } \\
\text { None }\end{array}$ & $\begin{array}{l}\text { Turbid } \\
\text { Clear } \\
\text { Clear }\end{array}$ & $\begin{array}{l}7.1 \text { to } 7.2 \\
\text { Approx. } \\
3.0 \\
3.0 \text { to } 3.5\end{array}$ & $\begin{array}{c}1.25 \\
\text { None } \\
\text { None }\end{array}$ & $\begin{array}{c}0.2 \\
0.02 \\
>0.02<0.04\end{array}$ \\
\hline
\end{tabular}

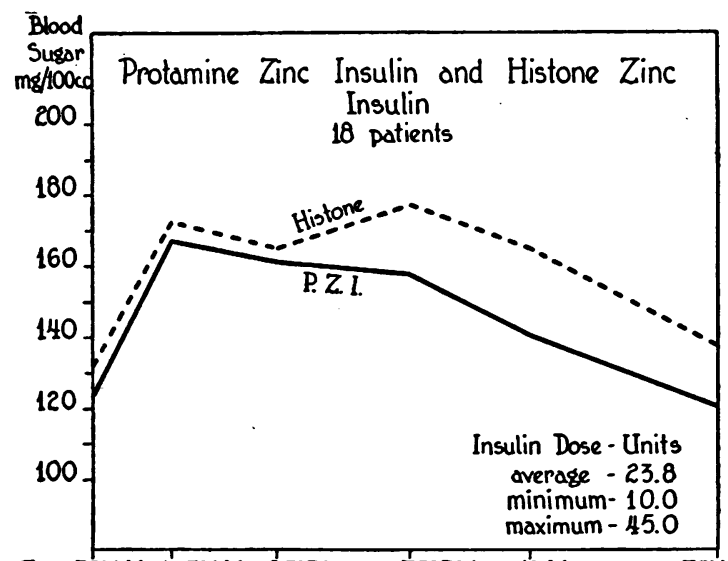

Time 7:30AM 10:30AM 2:30PM T:30 PM 12 M T:30AM

Fig. 1. Comparison of Protamine Zinc Insulin and Histone Insulin on 18 Patients

Composite 24-hour blood sugar curves.

determinations. If the fasting blood sugar at the beginning and the fasting blood sugar at the end of a 24-hour curve were not within reasonable proximity, it was concluded that the stabilization with that particular insulin was not satisfactory, and such curves were not included.

After all criteria were satisfied, reasonable stability secured, and a 24-hour curve obtained representing the type of regulation obtainable with one type of insulin, an equivalent dose of one of the other insulins was begun, all other conditions being left unaltered. After a similar period of stabilization, a 24-hour curve could be obtained with a second type of insulin, and later with a third or fourth type.

\section{RESULTS}

Histone zinc insulin. When compared on 18 patients with protamine zinc insulin, histone zinc insulin gave fairly good diabetic control, but was less effective per unit given. The tendency toward a more rapid initial action, which is so desirable, and which was suggested in the 4 patients of Bailey and Marble (6), was not evident in our series. There was less prolonged activity as shown by the higher fasting blood sugars. When the 2 insulins were compared in the same patients, fasting blood sugars were lowest with protamine zinc insulin in 61 per cent of the tests, with histone zinc insulin in only 9 per cent, while they were equivalent (within $10 \mathrm{mgm}$. per cent) in 30 per cent of the tests. Composite curves (Figure 1) show the essential differences between the 2 insulins. On the average, fasting blood sugars with histone zinc insulin were $10 \mathrm{mgm}$. per cent higher, at 10:30 a.m. were $7 \mathrm{mgm}$. per cent higher, 


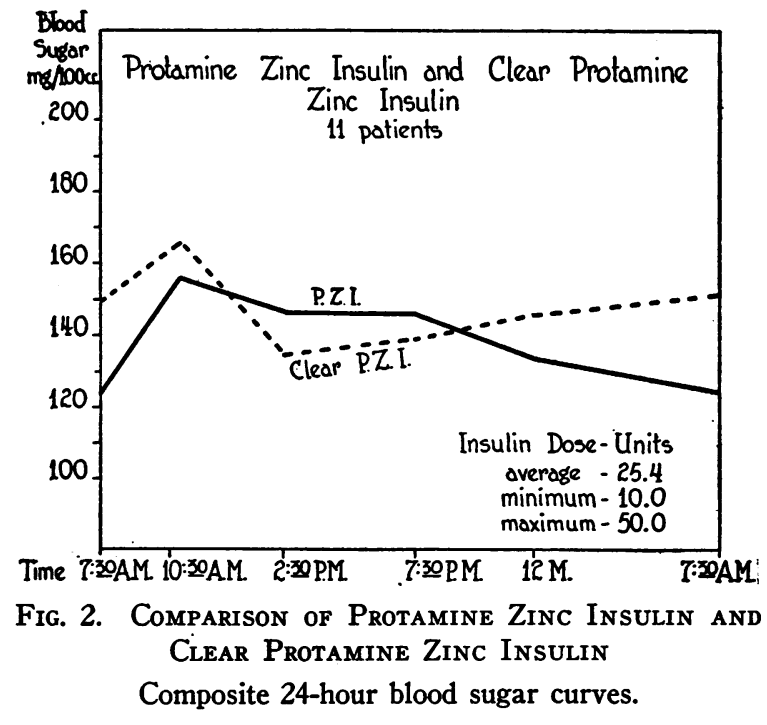

at 2:30 p.m. $3 \mathrm{mgm}$. per cent higher, at 7:30 p.m. $20 \mathrm{mgm}$. per cent higher, at 12 midnight $24 \mathrm{mgm}$. per cent higher. Although the higher fasting and midnight blood sugars might have been eliminated by omitting the night feedings, the tendency to rise at 7:30 p.m. could not be thus avoided, nor could the failure to depress the 10:30 and 2:30 blood sugars be explained except by the lack of the prompt acting quality we were seeking.

The general shapes of the curves obtained with histone zinc insulin and with protamine zinc insulin are similar, there being a considerable rise after breakfast, a fall after lunch, then a gradual fall back toward the fasting level. If we had used slightly larger doses of histone zinc insulin rather than equivalent doses, the effectiveness might have approached that of market protamine zinc insulin. With equivalent doses, protamine zinc insulin was more effective per unit and gave better control throughout the 24 hours, while histone zinc insulin failed to exhibit the desired more prompt action.

Clear protamine zinc insulin. When compared on 11 patients with protamine zinc insulin, clear protamine zinc insulin gave less satisfactory diabetic control. The clear insulin failed to depress the 10:30 a.m. blood sugar, which is usually the highest blood sugar during the day when protamine zinc insulin is used. In most instances, the 2:30 p.m. blood sugar was definitely lower with the clear insulin, as was the 7:30 p.m. sugar, while the midnight and fasting blood sugars were higher.
Seventeen of 22 fasting blood sugars ( 77 per cent) were lowest with market protamine zinc insulin. The shorter duration of activity is a desirable feature, at least to some extent, but the comparative curves (Figure 2) show that with equivalent doses, the clear insulin had too little sustained effect, at the same time exhibiting too little initial activity. If we had used enough of the clear insulin to obtain normal fasting blood sugars, we should certainly have had to resort to a midafternoon feeding, as have others (6), to prevent hypoglycemic reactions. On the average, blood sugars with clear protamine zinc insulin were 26 mgm. per cent higher fasting, $10 \mathrm{mgm}$. per cent higher at 10:30 a.m., 9 mgm. per cent lower at 2:30 p.m., 7 mgm. per cent lower at 7:30 p.m., and $14 \mathrm{mgm}$. per cent higher at midnight.

The general shapes of the curves obtained with clear protamine zinc insulin and with market protamine zinc insulin are dissimilar, the clear insulin allowing a rise after breakfast, as does turbid protamine zinc insulin, but causing a steep fall in the afternoon, and permitting a considerable rise during the night, so that the mid-afternoon sugar is lowest, rather than the fasting levels, as is true with market protamine zinc insulin.

With equivalent doses, market protamine zinc insulin gave better diabetic control than clear protamine zinc insulin, while the latter failed to exhibit the prompt morning action desired. The clear insulin caused too great an afternoon fall, and its duration of activity was too short, permitting fasting blood sugar levels higher than desirable.

"Three-to-one" modified protamine zinc insulin. This special insulin gave much better results than any other modified insulin we have investigated. We have divided this study into two parts: I. Comparison of " $3: 1$ " insulin with equal doses of protamine zinc insulin. II. Comparison of " $3: 1$ " insulin with combined regular and protamine zinc insulin regulation.

I. "Three-to-one" insulin when compared with market protamine zinc insulin in 11 patients gave better diabetic control, with a definite tendency to give lower blood sugars at mid-morning, midafternoon and early evening, slightly higher sugars at midnight, and equal fasting blood sugars. Thus, the desired objectives of lower blood sugars 
during the day, and avoidance of nocturnal hypoglycemia seem to be accomplished with this new protamine zinc insulin modification. The individual comparative blood sugar figures are given in Table II.

The average blood sugar rise permitted after breakfast by protamine zinc insulin was $78 \mathrm{mgm}$. per cent, while with " $3: 1$ " insulin it was only 50 mgm. per cent. At 2:30 p.m., the average blood sugar after " $3: 1$ " insulin was $16 \mathrm{mgm}$. per cent lower, at $7: 30$ p.m. 4 mgm. per cent lower, at midnight $10 \mathrm{mgm}$. per cent higher, while the fasting blood sugars gave almost exactly the same aver-

TABLE II

Comparative 24-hour blood sugar curves

Comparison of " $3: 1$ " insulin with equal doses of protamine zinc insulin.

\begin{tabular}{|c|c|c|c|c|c|c|c|c|}
\hline \multirow{2}{*}{$\begin{array}{l}\text { Case } \\
\text { num- } \\
\text { ber }\end{array}$} & \multirow{2}{*}{\multicolumn{2}{|c|}{ Insulin dose }} & \multicolumn{6}{|c|}{ Blood sugar } \\
\hline & & & $\begin{array}{l}\text { 7:30 } \\
\text { a.m. }\end{array}$ & $\begin{array}{c}\text { 10:30 } \\
\text { a.m. }\end{array}$ & $\begin{array}{l}\text { 2:30 } \\
\text { p.m. }\end{array}$ & $\begin{array}{l}\text { 7:30 } \\
\text { p.m. }\end{array}$ & $\begin{array}{c}12 \\
\text { p.m. }\end{array}$ & $\begin{array}{l}\text { 7:30 } \\
\text { a.m. }\end{array}$ \\
\hline & & & \multicolumn{6}{|c|}{ mgm. per $100 \mathrm{cc}$. } \\
\hline 1 & “" PZI:1" & $\begin{array}{l}35 \\
35\end{array}$ & $\begin{array}{l}157 \\
129\end{array}$ & $\begin{array}{l}230 \\
197\end{array}$ & $\begin{array}{l}196 \\
148\end{array}$ & $\begin{array}{l}217 \\
223\end{array}$ & $\begin{array}{l}164 \\
137\end{array}$ & $\begin{array}{l}137 \\
132\end{array}$ \\
\hline 2 & “" PZI, & $\begin{array}{l}15 \\
15\end{array}$ & $\begin{array}{r}80 \\
107\end{array}$ & $\begin{array}{l}175 \\
112\end{array}$ & $\begin{array}{l}214 \\
166\end{array}$ & $\begin{array}{l}213 \\
220\end{array}$ & $\begin{array}{l}150 \\
186\end{array}$ & $\begin{array}{l}105 \\
107\end{array}$ \\
\hline 3 & “PZI & $\begin{array}{l}30 \\
30\end{array}$ & $\begin{array}{l}79 \\
91\end{array}$ & $\begin{array}{l}180 \\
181\end{array}$ & $\begin{array}{l}208 \\
164\end{array}$ & $\begin{array}{l}209 \\
194\end{array}$ & $\begin{array}{l}211 \\
175\end{array}$ & $\begin{array}{l}100 \\
123\end{array}$ \\
\hline 4 & “PZI" & $\begin{array}{l}35 \\
35\end{array}$ & $\begin{array}{r}95 \\
142\end{array}$ & $\begin{array}{l}159 \\
155\end{array}$ & $\begin{array}{l}121 \\
138\end{array}$ & $\begin{array}{l}105 \\
209\end{array}$ & $\begin{array}{r}81 \\
132\end{array}$ & $\begin{array}{r}83 \\
111\end{array}$ \\
\hline 5 & “"3:1”, & $\begin{array}{l}35 \\
35\end{array}$ & $\begin{array}{l}150 \\
136\end{array}$ & $\begin{array}{l}230 \\
155\end{array}$ & $\begin{array}{l}178 \\
143\end{array}$ & $\begin{array}{l}225 \\
160\end{array}$ & 175 & $\begin{array}{l}157 \\
119\end{array}$ \\
\hline 6 & “PZI & $\begin{array}{l}30 \\
30\end{array}$ & 153 & $\begin{array}{l}220 \\
155\end{array}$ & $\begin{array}{l}210 \\
143\end{array}$ & $\begin{array}{r}164 \\
96\end{array}$ & $\begin{array}{l}209 \\
144\end{array}$ & $\begin{array}{r}159 \\
85\end{array}$ \\
\hline 7 & “(3:1”, & $\begin{array}{l}15 \\
15\end{array}$ & $\begin{array}{r}99 \\
122\end{array}$ & $\begin{array}{l}159 \\
168\end{array}$ & $\begin{array}{l}145 \\
151\end{array}$ & $\begin{array}{l}162 \\
148\end{array}$ & $\begin{array}{l}190 \\
148\end{array}$ & $\begin{array}{l}122 \\
128\end{array}$ \\
\hline 8 & $\begin{array}{c}\text { PZI } \\
\text { “3:1” }\end{array}$ & $\begin{array}{l}15 \\
15\end{array}$ & $\begin{array}{r}99 \\
119\end{array}$ & $\begin{array}{l}159 \\
122\end{array}$ & $\begin{array}{l}145 \\
136\end{array}$ & $\begin{array}{l}162 \\
114\end{array}$ & $\begin{array}{l}190 \\
140\end{array}$ & $\begin{array}{l}122 \\
120\end{array}$ \\
\hline 9 & “"3:1", & $\begin{array}{l}25 \\
25\end{array}$ & $\begin{array}{l}137 \\
123\end{array}$ & $\begin{array}{l}235 \\
157\end{array}$ & $\begin{array}{l}214 \\
197\end{array}$ & $\begin{array}{l}237 \\
132\end{array}$ & $\begin{array}{l}223 \\
182\end{array}$ & $\begin{array}{l}100 \\
109\end{array}$ \\
\hline 10 & “" PZI:1" & $\begin{array}{l}25 \\
25\end{array}$ & $\begin{array}{l}66 \\
74\end{array}$ & $\begin{array}{r}99 \\
103\end{array}$ & $\begin{array}{l}137 \\
135\end{array}$ & $\begin{array}{l}130 \\
191\end{array}$ & $\begin{array}{r}86 \\
141\end{array}$ & $\begin{array}{l}60 \\
94\end{array}$ \\
\hline 11 & “PZI, & $\begin{array}{l}15 \\
15\end{array}$ & $\begin{array}{l}105 \\
117\end{array}$ & $\begin{array}{l}205 \\
224\end{array}$ & $\begin{array}{l}215 \\
220\end{array}$ & $\begin{array}{l}176 \\
189\end{array}$ & $\begin{array}{l}197 \\
117\end{array}$ & $\begin{array}{l}135 \\
144\end{array}$ \\
\hline
\end{tabular}

Statistical analysis of these figures indicates that the better results obtained with the " $3: 1$ " insulin are not due to sampling error. At 10:30 a.m., for example, the time of the most definite improvement in the 24-hour blood sugar curves, the statistical probable significance of the differences is 0.978. According to Fisher's formula, a result of 0.95 or greater is statistically significant.

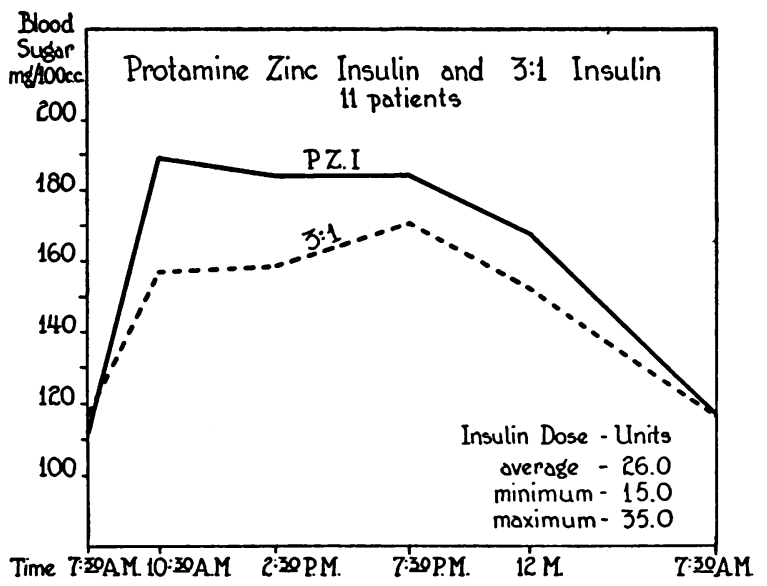

Fig. 3. Comparison of Protamine Zinc Insulin and "3: 1" Modifikd Protamine Zinc Insulin Composite 24-hour blood sugar curves.

age as with protamine zinc insulin. When compared with equal doses of market protamine zinc insulin in the 11 patients, fasting blood sugars were slightly lower with " $3: 1$ " insulin in 20 per cent of the determinations, slightly higher in 41 per cent, equal (within $10 \mathrm{mgm}$. per cent) in 39 per cent. The blood sugars at 10:30 a.m. were lower with " $3: 1$ " insulin 6 times out of 11 , equivalent 4 times, slightly lower with protamine zinc insulin once. At 2:30 p.m. likewise, " $3: 1$ " insulin gave the lowest blood sugars 6 times out of 11 , equivalent 4 times, while protamine zinc insulin gave a slightly lower figure once. At 7:30 p.m., the " $3: 1$ " insulin gave the lowest figures 6 times, protamine zinc insulin 3 times, while they were equivalent twice. At midnight, the " $3: 1$ " insulin gave the lowest figures 7 times, protamine zinc 3 times, while they were equivalent once. Examination of the composite curves (Figure 3 ) reveals that there is great similarity between the actions of the 2 insulins, except for the definite tendency to greater depression of the blood sugar during the day exhibited by the " 3 to 1 " protamine zinc insulin modification.

II. Comparison of " $3: 1$ " insulin with combined protamine zinc and regular insulin therapy: $6 \mathrm{pa}-$ tients showed as good regulation, or better, with " $3: 1$ " insulin as with combined therapy. In each of these 6 cases, the best possible regulation was secured with a larger dose of protamine zinc insulin and a smaller dose of regular insulin, and then 24-hour blood sugar curves were obtained. 


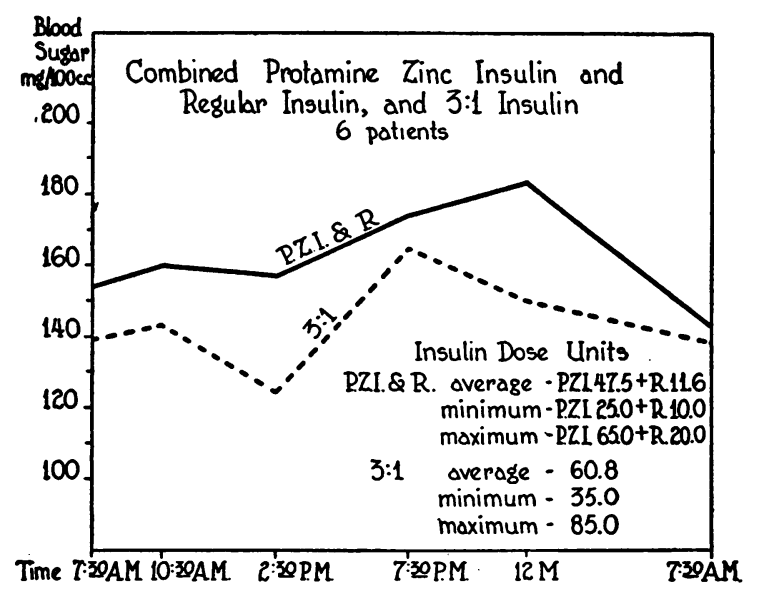

Fig. 4. Comparison of " $3: 1$ " Protamine Zinc Insulin with Combined Protamine Zinc and Regular INSULIN THERAPY

Composite 24-hour blood sugar curves.

The same patients were then each controlled with doses of " $3: 1$ " insulin, equal in amount to the previous total daily insulin requirements. The doses used in the 6 cases were 65 units of protamine zinc insulin and 20 units of regular insulin in 1 instance, 60 and 10 units, respectively, in 3 instances, and 25 and 10 units, respectively, in 2 instances. The ratios ranged from $6: 1$ to $2.5: 1$, averaging $3.9: 1$. The doses of " $3: 1$ " insulin used for comparison were therefore $85,70,70,70$, 35 , and 35 units, respectively. With the " $3: 1$ " insulin, the diabetic control was even better than that obtained by using the best possible proportions of protamine zinc and regular insulin in separate injections (Figure 4). In the composite 24-hour curve, it is evident that the " $3: 1$ " insulin is more effective per unit, and that it prevents the blood sugar rise after meals as successfully as the separate injections of regular insulin. While exhibiting the desirable rapid initial activity, it also has an even better prolonged action than is obtained in the combined therapy, as shown by the lower fasting blood sugars, and the lower midnight sugar. With the " $3: 1$ " insulin, there was no tendency toward hypoglycemia late at night or in the early morning hours, which certainly would have occurred in these cases with comparably large doses of protamine zinc insulin. The blood sugar values for the comparative curves with " $3: 1$ " insulin are given in Table III.

\section{DISCUSSION}

Some workers $(7,10)$ have obtained encouraging results with insulin-protamine zinc insulin mixtures, without readjustment of the $\mathrm{pH}$ to that of body tissues. If the resultant $\mathrm{pH}$ is near 5 , the iso-electric point of insulin, all of the insulin is in precipitated form. Peck (14) has shown that buffering to $\mathrm{pH} 7.2$, of a mixture of 2 parts of insulin with 1 part of protamine zinc insulin, results in 50 per cent of the insulin being present in rapidly-acting form. It would seem possible that the change to $\mathrm{pH} \mathrm{7.2,} \mathrm{occurring} \mathrm{after} \mathrm{subcutaneous}$ injection of unbuffered mixtures, might result in the release of excess amounts of rapidly acting insulin. We have observed blood sugar responses suggesting this in a few patients treated with such preparations.

Insulin made by mixing equal parts of protamine zinc insulin and regular insulin with buffer added to adjust the $\mathrm{pH}$ to 7.2 , provides a preparation containing 3 parts of precipitated insulin to 1 part of soluble insulin. This " $3: 1$ " insulin is stable, and since its $\mathrm{pH}$ is that of the body fluids, there is no variable factor resulting from $\mathrm{pH}$ change after injection. When small doses were

TABLE III

Comparative 24-hour blood sugar curves

Comparison of " $3: 1$ " insulin with separate injections of protamine zinc insulin and regular insulin.

\begin{tabular}{|c|c|c|c|c|c|c|c|}
\hline \multirow{2}{*}{$\begin{array}{c}\text { Case } \\
\text { num- } \\
\text { ber }\end{array}$} & \multirow{2}{*}{ Insulin dose } & \multicolumn{6}{|c|}{ Blood sugar } \\
\hline & & $\begin{array}{l}7: 30 \\
\text { a.m. }\end{array}$ & $\begin{array}{c}10: 30 \\
\text { a.m. }\end{array}$ & $\begin{array}{l}\text { 2:30 } \\
\text { p.m. }\end{array}$ & $\begin{array}{l}\text { 7:30 } \\
\text { p.m. }\end{array}$ & $\begin{array}{c}12 \\
\text { p.m. }\end{array}$ & $\begin{array}{l}7: 30 \\
\text { a.m. }\end{array}$ \\
\hline & & \multicolumn{6}{|c|}{ mgm. per $100 \mathrm{cc}$. } \\
\hline 12 & $\underset{3: 1}{\text { PZI }} 65+\underset{85}{\text { Reg. }} 20$ & $\begin{array}{l}159 \\
123\end{array}$ & $\begin{array}{r}181 \\
99\end{array}$ & $\begin{array}{l}197 \\
107\end{array}$ & $\begin{array}{l}218 \\
149\end{array}$ & $\begin{array}{l}220 \\
165\end{array}$ & $\begin{array}{l}115 \\
153\end{array}$ \\
\hline 13 & $\underset{3: 1}{\text { PZI }} 60+\underset{70}{\text { Reg. }} 10$ & $\begin{array}{l}81 \\
61\end{array}$ & $\begin{array}{l}117 \\
145\end{array}$ & $\begin{array}{l}156 \\
135\end{array}$ & $\begin{array}{l}194 \\
134\end{array}$ & $\begin{array}{l}261 \\
179\end{array}$ & $\begin{array}{l}140 \\
116\end{array}$ \\
\hline 14 & $\underset{3: 1}{\text { PZI }} 25+\underset{35}{\text { Reg. }} 10$ & $\begin{array}{l}128 \\
142\end{array}$ & $\begin{array}{l}167 \\
155\end{array}$ & $\begin{array}{r}95 \\
138\end{array}$ & $\begin{array}{l}144 \\
209\end{array}$ & $\begin{array}{l}119 \\
132\end{array}$ & $\begin{array}{l}109 \\
111\end{array}$ \\
\hline 15 & $\underset{3: 1}{\text { PZI }} 25+\underset{35}{\text { Reg. }} 10$ & $\begin{array}{l}157 \\
131\end{array}$ & $\begin{array}{l}148 \\
117\end{array}$ & $\begin{array}{r}155 \\
87\end{array}$ & $\begin{array}{l}148 \\
159\end{array}$ & $\begin{array}{l}112 \\
155\end{array}$ & $\begin{array}{l}135 \\
127\end{array}$ \\
\hline 16 & $\underset{3: 1}{\text { PZI }} 60+\underset{70}{\text { Reg. }} 10$ & $\begin{array}{l}257 \\
213\end{array}$ & $\begin{array}{l}263 \\
204\end{array}$ & $\begin{array}{l}219 \\
155\end{array}$ & $\begin{array}{l}240 \\
175\end{array}$ & $\begin{array}{l}213 \\
135\end{array}$ & $\begin{array}{l}246 \\
191\end{array}$ \\
\hline 17 & $\underset{3: 1}{\text { PZI }} 60+\underset{70}{\text { Reg. }} 10$ & $\begin{array}{l}141 \\
166\end{array}$ & $\begin{array}{r}84 \\
138\end{array}$ & $\begin{array}{l}118 \\
123\end{array}$ & $\begin{array}{l}102 \\
164\end{array}$ & $\begin{array}{l}176 \\
136\end{array}$ & $\begin{array}{l}112 \\
131\end{array}$ \\
\hline
\end{tabular}

Statistical analysis of these figures indicates that " $3: 1$ " insulin gave better results than "combined therapy." At 10:30 a.m. and 2:30 p.m., the statistical probable significance of the differences favoring " $3: 1$ " insulin is 0.959 . 
used, the effects differed little from those obtained with standard protamine zinc insulin. This feature is desirable, since too much initial activity in mild diabetes will cause hypoglycemia. A morning injection of 20 units, for example, gave approximately 15 units of slow effect and only 5 units of rapid effect. When larger doses such as 60 units daily were required, there were 45 units of slow effect and 15 units of rapid insulin activity, as demanded by the severity of the diabetes, and the greater tendency to postprandial hyperglycemia.

\section{SUMMARY AND CONCLUSIONS}

1. Comparative studies on 17 diabetic patients with a new modification of protamine zinc insulin gave better results than those obtained with the usual forms of insulin therapy. A single injection daily took the place of standard protamine zinc insulin in regulating patients with mild diabetes. One injection was also sufficient to control more severe diabetes, previously requiring separate injections daily of protamine zinc insulin and regular insulin.

2. Comparative studies on 18 patients with histone zinc insulin revealed poorer diabetic control than that obtained with standard protamine zinc insulin. The desirable more rapid initial action was lacking, and there was less prolonged effect.

3. Comparative studies on 11 patients with clear (acid or soluble) protamine zinc insulin gave less satisfactory control than that secured with standard protamine zinc insulin. Clear protamine zinc insulin had too little sustained effect and showed insufficient rapid activity.

4. A new insulin modification containing 3 parts of precipitated insulin to 1 part of soluble insulin provided better control in the patients studied than that obtained with other modifications or combinations of insulin. It is made by mixing equal parts of protamine zinc insulin and regular insulin with buffer added to adjust the $\mathrm{pH}$ to 7.2 .

5. Multiple forms of insulin are not necessary, and their use should be discouraged. Two forms of insulin should be sufficient: (1) a modified protamine zinc insulin such as that described in these studies, used for controlling uncomplicated dia- betes; (2) regular (or crystalline) insulin, to be employed whenever emergency therapy is necessary.

\section{BIBLIOGRAPHY}

1. a. Joslin, E. P., Protamine insulin. J. A. M. A., 1937, 109, 497.

b. Mosenthal, H. O., Protamine zinc insulin; clinical application. J. A. M. A., 1938, 110, 87.

c. MacBryde, C. M., Diabetes; advances in treatment. J. Missouri M. A., 1941, 38, 3.

d. Peck, F. B., Therapeutic application of the various insulins. South. Med. and Surg., 1941, 103, 539.

2. Hagedorn, H. C., Jensen, B. N., Krarup, N. B., and Wodstrup, I., Protamine insulinate. J. A. M. A., 1936, 106, 177.

3. Biasotti, A., Deulofeu, V., and Mendive, J. R., Acción de la insulina-histona sobre la glucemia. Prensa méd. argent., 1937, 24, 1122.

4. Gray, P. A., Bischoff, F., and Sansum, W. D., Treatment of diabetes mellitus with insoluble insulin compounds. II. Histone-insulin. Ann. Int. Med., 1937, 11, 274.

5. Barnes, C. A., Cuttle, T. D., and Duncan, G. G., Histone zinc insulin, its pharmacologic characteristics and its application in the treatment of diabetes mellitus. J. Pharmacol. and Exper. Therap., 1941, 72, 331.

6. Bailey, C. C., and Marble, A., Histone zinc insulin, globin (zinc) insulin, and clear protamine zinc insulin; a comparative study of their action. J. A. M. A., 1942, 118, 683.

Andrews, G. B., and Groat, W. A., Globin insulin; a clinical study. New York State J. Med., 1940, 40, 913.

7. Colwell, A. R., Izzo, J. L., and Stryker, W. A., Intermediate action of mixtures of soluble insulin and protamine zinc insulin. Arch. Int. Med., 1942, 69, 931.

8. Joslin, E. P., et al., Treatment of Diabetes Mellitus. Lea and Febiger, Philadelphia, 1940. 7th Ed., p. 286.

9. Wauchope, G. M., Zinc protamine insulin and soluble insulin interaction in combined doses. Lancet, 1940, $1,962$.

10. Ulrich, H., Clinical experiments with mixtures of standard and protamine zinc insulins. Ann. Int. Med., 1941, 14, 1166.

11. Bjuggren, S., Question of mixing common insulin with protamine zinc insulin before injection. Nord. med. (Hygiea), 1939, 4, 3099.

12. Masters, T. D., The use of the newer insulins. Illinois M. J., 1940, 78, 319.

13. Wilder, R. M., Clinical Diabetes Mellitus and Hyperinsulinism. W. B. Saunders Co., Philadelphia, 1940, p. 92.

14. Peck, F. B., Action of insulins. Proc. Am. Diabetes A., $1942,2,67$. 